\title{
“PENGEMBANGAN KARIR DAN DISIPLIN KERJA TERHADAP KINERJA KARYAWAN MELALUI KEPUASAN KERJA SEBAGAI VARIABEL INTERVENING PADA PT XYZ"
}

\author{
Oleh: \\ Dedi Rianto Rahadi ${ }^{1}$ dan Claudia Ocktaliani ${ }^{2}$ \\ Email : ${ }^{1}$ dedi1968@president.ac.id, ${ }^{2}$ \\ President University
}

\begin{abstract}
Abstrak
Kinerja adalah hasil kerja secara kualitas dan kuantitas yang dapat di capai oleh seorang karyawan dalam melaksanakan tugas sesuai dengan tanggung jawab yang diberikan kepada karyawan tersebut. Kedisiplinan merupakan fungsi operatif manajemen sumber daya manusia yang terpenting karena semakin baik disiplin karyawan, semakin tinggi prestasi kerja yang dapat dicapai. Pengembangan karir karyawan didasari atas keinginan dan usaha sendiri melatih dan mengembangkan dirinya yang berhubungan dengan pekerjaan atau jabatannya. Penelitian bertujuan untuk menganalisis pengaruh pengembangan kerja, disiplin kerja, kepuasan kerja dan kinerja karyawan. Responden penelitian adalah karyawan PT.XYZ, dengan jumlah responden sebanyak 150 orang. Metode penelitian adalah analisis jalur dan pengumpulan data melalui penyebaran kuisioner. Hasil penelitian menunjukan bahwa pengembangan karir terhadap kepuasan kerja adalah signifikan, pengaruh disiplin kerja terhadap kepuasan kerja adalah tidak signifikan. Pengembangan karir terhadap kinerja karyawan adalah signifikan dan disiplin kerja terhadap kinerja karyawan adalah signifikan. Saran bagi PT.XYZ yang menjadi objek penelitian ini khususnya perlu melakukan pengawasan terhadap displin kinerja beberapa pengembangan karir dalam meningkatkan kepuasan kerja dan kinerja karyawan.
\end{abstract}

Kata Kunci: Pengembangan Karir, Disiplin Kerja, Kepuasan Kerja dan Kinerja

\begin{abstract}
Performance is the result of quality and quantity of work that can be achieved by an employee in carrying out tasks in accordance with the responsibilities given to the employee. Discipline is the most important operative function of human resource management because the better employee discipline is, the higher work performance can be achieved. Employees' career development is based on their own desires and efforts to train and develop themselves in relation to their work or position. The research aims to analyze the effect of work development, work discipline, job satisfaction and employee performance. The research respondents were employees of PT. XYZ, with a total of 150 respondents. The research method is path analysis and data collection through questionnaires. The results showed that career development on job satisfaction was significant, the effect of work discipline on job satisfaction was not significant. Career development on employee performance is significant and work discipline on employee performance is significant. Suggestions for PT. XYZ who are the object of this study in particular need to supervise the performance discipline of some career development in increasing job satisfaction and employee performance.
\end{abstract}

Keywords: Career Development, Work Discipline, Job Satisfaction and Performance 


\section{A. Latar Belakang}

Menurut Handoko (2001) sumber daya yang penting di dalam perusahaan merupakan sumber daya manusia yaitu orang-orang yang memberikan tenaga, bakat, kreatifitas dan setiap usaha mereka terhadap organisasi. Pengolahan sumber daya manusia (SDM) yang baik merupakan upaya-upaya untuk meningkatkan kinerja dan mengembangkan kualitas SDM sebagai pelaku dalam sebuah perusahaan. SDM atau karyawan merupakan salah satu asset yang paling penting dalam keberhasilan perusahaan. Keberhasilan disuatu perusahaan dapat dicapai dengan meningkatkan kinerja para karyawannya. Adapun pengertian kinerja menurut (Rivai (2011) merupakan hasil kerja yang dapat dicapai oleh seseorang dalam suatu perusahaan sesuai dengan wewenang dan tanggung jawabnya masing-masing dalam upaya pencapaian dalam tujuan perusahaan secara legal, tidak melanggar hukum dan tidak bertentangan dengan nilai-nilai moral. Pengembangan karir Menurut Robbins (1996) adalah suatu yang menunjukkan adanya peningkatan-peningkatan status seseorang dalam suatu organisasi dalam jalur karir yang telah ditetapkan dalam organisasi yang bersangkutan. Pengembangan karir sangat diperlukan karena karir merupakan kebutuhan yang harus terus dikembangkan dalam diri seorang karyawan sehingga mampu memotivasi karyawan untuk meningkatkan kinerjanya.

Rivai (2011) menyatakan disiplin kerja adalah suatu alat yang dipergunakan para manajer untuk berkomunikasi dengan karyawan agar mereka bersedia untuk mengubah suatu prilaku serta sebagai suatu upaya untuk meningkatkan kesadaran dan kesediaan seorang dalam memenuhi segala perarturan perusahaan. Menurut Anoraga (2009) kepuasan kerja merupakan suatu sikap yang positif yang menyangkutkan penyesuaian diri yang sehat dari para karyawan terhadap kondisi dan situasi kerja, termasuk didalamnya masalah upah, kondisi social, kondisi fisik dan kondisi psikologis. Howell dan Dipboye (1986) dalam Munandar (2010) memandang kepuasan kerja sebagai hasil keseluruhan dari derajat rasa suka atau tidak sukanya tenaga kerja terhadap berbagai aspek dari pekerjaannya.

Dari uraian diatas penulis ingin menganalisis apakah hasil pra survey menunjukkan hasil yang sesuai dengan kondisi dilapangan. Berdasarkan uraian tersebut, maka peneliti tertarik 
melakukan penelitian dengan judul "Pengembangan Karir, Disiplin Kerja Terhadap Kinerja Karyawan Melalui Kepuasan Kerja Sebagai Variabel Intervening pada PT XYZ”

\section{B. Landasan Teori}

\section{Pengembangan Karir}

Sunyoto (2012) perencanaan karir adalah proses yang dilalui oleh individu karyawan untuk mengindetifikasi dan mengambil langkah-langkah untuk mencapai tujuan karir. Dengan demikian seorang karyawan perlu mengambil langkah-langkah tertentu guna mewujudkan rencana tersebut. Berbagai langkah yang perlu di tempuh itu dapat diambil akan prakarsa pekerja sendiri, tetapi dapat pula berupa kegiatan yang disponsori oleh organisasi, atau gabungan dari keduanya. Hal ini merupakan salah satu prinsip pengembangan karir yang sangat fundamental sifatnya.

\section{Disiplin Kerja}

Disiplin kerja karyawan sangat penting bagi perusahaan dalam rangka mewujudkan instansi. Tampa disiplin kerja yang baik, sulit bagi suatu instansi mencapai hasil yang optimal. Disiplin kerja mencerminkan besarnya rasa tanggung jawab seseorang terhadap tugas-tugasnya yang diberikan kepadanya. Hal ini mendorong semangat kerja merupakan kunci keberhasilan instansi dalam mencapai tujuannya. Berikut ini pengertian disiplin kerja yang dikemukakan oleh para ahli, yaitu Menurut Keith Davis terjemahan Agus Dharma (2010), "Disiplin kerja adalah tindakan manajemen untuk memberikan semangat kepada pelaksanan standar organisasi, ini merupakan salah satu platihan yang mengarah pada upaya membenarkan dan melibatkan pengetahuan, sikap dan prilaku sehingga ada kemauan pada diri

\section{Kepuasan Kerja}

Menurut Robin (2006) dalam Riyanto (2016) kepuasan kerja adalah sikap umum terhadap pekerjaan seseorang, yang menunjukan perbedaan antara jumlah penghargaan yang di terima pekerjaan dan jumlah yang mereka yakini seharusnya mereka terima. Robbins (2003) dalam Riyanto (2016) menyatakan kepuasaan kerja adalah merujuk kesikap umum seseorang individu terhadap pekerjaannya seseorang dengan tingkat kepuasan kerja yang tinggi 
menunjukan sikap positif terhadap kerja, sedangkan seseorang yang tidak puas dengan pekerjaannya menunjukan sikap yang negatif terhadap pekerjaan itu sendiri. Menurut Hasibuan (2006) kepuasan kerja adalah sikap emosional yang menyenangkan dan mencintai pekerjaannya. Sikap ini mencerminkan oleh moral kerja, kedisiplinan dan kinerja. Menurut Zainun (2001) kepuasan kerja adalah cara seorang karyawan merasakan pekerjaannya yang umumum di wujudkan dalam sikap terhadap pekerjaannya, berdasarkan evaluasi dari aspek yang berada terhadap pekerjaannya. Sikap tersebut merupakan pencerminan pengalaman yang memberikan kesenangan serta ketidaksenangan dan pekerjaannya serta harapan akan pengalaman dimasa mendatang.

\section{Kinerja Karyawan}

Mangkunegara (2012) mengemukakan bahwa kinerja adalah hasil kerja secara kualitas dan kuantitas yang dicapai oleh seorang karyawan dalam melaksanakan tugasnya sesuai dengan tanggung jawab yang diberikan kepadanya. Menurut Wibowo (2009) kinerja karyawan merupakan implementasi perencanaan yang telah disusun tersebut. Implentasi kinerja karyawan dilakukan oleh sumber daya manusia yang memiliki kemampuan koma, kompetensi, motivasi dan kepentingan. Menurut Sulistiyani dan Rosidah (2003) kinerja merupakan catatan outcome yang dihasilkan dari fungsi karyawan tertentu atau kegiatan yang dilakukan selama periode waktu tertentu. Russel 2002 memberikan pengertian kinerja adalah catatan tentang hasil-hasil yang diperoleh dari fungsi-fungsi pekerjaan tertentu atau kegiatan selama kurun waktu yang ditentukan.

\section{Metode Penelitian}

Metode analisis yang digunakan adalah metode path analysis. Digunakan untuk menganalisis pola hubungan diantara variabel. Model ini untuk mengetahui pengaruh langsung maupun tidak langsung seperangkat variabel indenpendent terhadap denpendent Sani dan Maharani (2013) 


\section{Kerangka Pemikir}

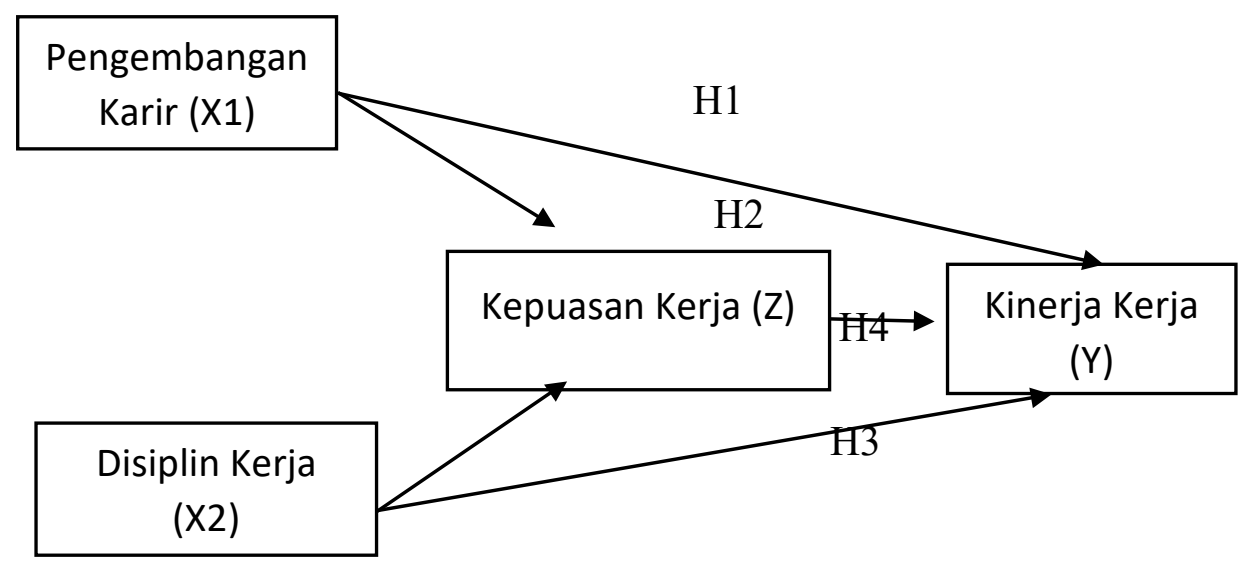

\section{Gambar 3.1 Kerangka Teoritis Regresi X1, X2, Z dan Y (Secara Umum)}

Sumber : Data Diolah 2019

\subsection{Hipotesis Penelitin}

H1 : $\quad$ Terdapat pengaruh langsung Pengembangan karir $\left(\mathrm{x}_{1}\right)$ terhadap kinerja karyawan (y). H2 :Terdapat pengaruh tidak langsung Pengembangan karir $\left(\mathrm{x}_{1}\right)$ terhadap kinerja karyawan (y) melalui kepuasan kerja (z). H3 :Terdapat pengaruh langsung Disiplin kerja $\left(\mathrm{x}_{2}\right)$ terhadap kinerja karyawan (y). H4 :Terdapat pengaruh tidak langsung Disiplin kerja $\left(\mathrm{x}_{2}\right)$ terhadap kinerja karyawan (y) melalui kepuasan kerja (z)

\section{Variabel Penelitian dan Definisi Operasional}

Tabel 1. Definisi Operasional Variabel

\begin{tabular}{|c|l|l|l|l|}
\hline No & \multicolumn{1}{|c|}{$\begin{array}{c}\text { Variabel } \\
\text { Penelitian }\end{array}$} & \multicolumn{1}{c|}{ Definisi } & Indikator & \multicolumn{1}{c|}{ Dimensi } \\
\hline 1 & $\begin{array}{l}\text { Disiplin Kerja } \\
(\mathrm{X} 2)\end{array}$ & $\begin{array}{l}\text { Hasibuan (2001) } \\
\text { kedisiplinan } \\
\text { merupakan fungsi } \\
\end{array}$ & $\begin{array}{l}\text { 1. Tujuan dan } \\
\text { kemampuan } \\
\text { operatif manajemen } \\
\text { sumber daya }\end{array}$ & $\begin{array}{l}\text { a. sesuai dengan jadwal } \\
\text { pekerjaan } \\
\text { b. target perusahaan } \\
\text { c. bertanggung jawab } \\
\text { terhadap pekerjaan }\end{array}$ \\
\hline
\end{tabular}




\begin{tabular}{|c|c|c|c|c|}
\hline & & \multirow{7}{*}{$\begin{array}{l}\text { manusia (MSDM) } \\
\text { yang terpenting } \\
\text { karena semakin } \\
\text { banyak disiplin } \\
\text { karyawan, semakin } \\
\text { tinggi juga prestasi } \\
\text { kerja yang di } \\
\text { capainya. }\end{array}$} & $\begin{array}{l}\text { 2. Teladan } \\
\text { kepemimpinan }\end{array}$ & $\begin{array}{l}\text { a. bekerja teladan } \\
\text { b. bekerja disiplin } \\
\text { c. bersikap adil }\end{array}$ \\
\hline & & & 3. Balas jasa & a. Upah, tunjangan \\
\hline & & & 4. Keadilan & $\begin{array}{l}\text { a. jadwal kerja adil } \\
\text { b. beban kerja adil } \\
\text { c. Tunjungan yang } \\
\text { diberikan ke semua } \\
\text { karyawan }\end{array}$ \\
\hline & & & $\begin{array}{l}\text { 5. Pengawasan melekat } \\
\text { (waskat) }\end{array}$ & $\begin{array}{l}\text { a. Pemimpin aktif } \\
\text { b. hadir di tempat kerja } \\
\text { c. memberikan pentunjuk }\end{array}$ \\
\hline & & & 6. Sanksi hukuman & sanksi hukuman karyawan \\
\hline & & & 7. Ketegasan & $\begin{array}{l}\text { a. Pemimpin tegas dan } \\
\text { berani mengambil tindakan } \\
\text { c. Sanksi diberikan sesuai } \\
\text { perarturan }\end{array}$ \\
\hline & & & $\begin{array}{l}\text { 8. Hubungan } \\
\text { kemanusiaan }\end{array}$ & $\begin{array}{l}\text { a. menjalin hub baik } \\
\text { dengan perusahaan } \\
\text { b. saling support antar } \\
\text { karyawan } \\
\text { c. memperlakukan } \\
\text { karyawan sesuai hak dan } \\
\text { kemanusiaan }\end{array}$ \\
\hline \multirow[t]{5}{*}{2} & \multirow[t]{5}{*}{$\begin{array}{l}\text { Pengembangan } \\
\text { Karir (X1) }\end{array}$} & \multirow{5}{*}{$\begin{array}{l}\text { Sunyoto (2012) } \\
\text { perencanaan karir } \\
\text { adalah proses yang } \\
\text { dilalui oleh individu } \\
\text { karyawan untuk } \\
\text { mengindetifikasi dan } \\
\text { mengambil langkah- } \\
\text { langkah untuk } \\
\text { mencapai tujuan } \\
\text { karirnya. }\end{array}$} & 1. Kebijakan Organisasi & $\begin{array}{l}\text { a. tujuan karir } \\
\text { b. Posisi bekerja sesuai } \\
\text { c. di berikan kesempatan } \\
\text { untuk seleksi }\end{array}$ \\
\hline & & & 2. Prestasi kerja & $\begin{array}{l}\text { a. Penilaian perusahaan } \\
\text { b. memberikan } \\
\text { penghargaan } \\
\text { c. Prestasi kerja karyawan }\end{array}$ \\
\hline & & & $\begin{array}{l}\text { 3. Latar belakang } \\
\text { pendidikan }\end{array}$ & $\begin{array}{l}\text { a. penentuan jabatan } \\
\text { b. mempengaruhi gaji } \\
\text { c. Posisi bekerja }\end{array}$ \\
\hline & & & 4. Pelatih & $\begin{array}{l}\text { a. diberikan pelatih untuk } \\
\text { seleksi } \\
\text { b. Prestasi kerja karyawan } \\
\text { c. pelatih perusahaan }\end{array}$ \\
\hline & & & 5. Pengalaman kerja & $\begin{array}{l}\text { a. memahami pekerjaan } \\
\text { b. Pengalaman kerja } \\
\text { c. pengalaman untuk } \\
\text { mengurangi masalah }\end{array}$ \\
\hline
\end{tabular}




\begin{tabular}{|c|c|c|c|c|}
\hline & & & $\begin{array}{l}\text { 6. Kesetiaan pada } \\
\text { organisasi }\end{array}$ & $\begin{array}{l}\text { a. setia pada perusahaan } \\
\text { b. memiliki perusahaan } \\
\text { c.terikat secara emosional }\end{array}$ \\
\hline & & & $\begin{array}{l}\text { 7. Keluwesan bergaul } \\
\text { dan hubungan antar } \\
\text { manusia }\end{array}$ & $\begin{array}{l}\text { a. kerja sama } \\
\text { b. pemecahan masalah } \\
\text { c. Saran dan kritik dari } \\
\text { rekan kerja }\end{array}$ \\
\hline \multirow[t]{8}{*}{3} & \multirow[t]{8}{*}{$\begin{array}{l}\text { Kepuasan Kerja } \\
\text { (Z) }\end{array}$} & \multirow{8}{*}{$\begin{array}{l}\text { Riyanto (2016) } \\
\text { menyatakan } \\
\text { kepuasan kerja } \\
\text { adalah merujuk ke } \\
\text { sikap umum } \\
\text { seseorang individu } \\
\text { terhadap } \\
\text { pekerjaannya } \\
\text { seseorang dengan } \\
\text { tingkat kepuasan } \\
\text { kerja yang tinggi } \\
\text { menunjukan sikap } \\
\text { positif terhadap } \\
\text { kerja, sedangkan } \\
\text { seseorang yang tidak } \\
\text { puas dengan } \\
\text { pekerjaanya } \\
\text { menunjukan sikap } \\
\text { yang negatif } \\
\text { terhadap pekerjaan } \\
\text { itu sendiri. }\end{array}$} & 1. Kesetiaan & $\begin{array}{l}\text { a. visi misi perusahaan } \\
\text { b. memajukan organisasi } \\
\text { c. karir perusahaan }\end{array}$ \\
\hline & & & 2. Kemampuan & $\begin{array}{l}\text { a. fasilitas perusahaan } \\
\text { b. kemampuan pekerjaan } \\
\text { c. kerja sama dengan rekan } \\
\text { kerja dan atasan }\end{array}$ \\
\hline & & & 3. Kejujuran & $\begin{array}{l}\text { a. Bersikap terbuka } \\
\text { terhadap masalah } \\
\text { c. Melaporkan kejadian }\end{array}$ \\
\hline & & & 4. Kreatifitas & $\begin{array}{l}\text { a. Mengusulkan cara baru } \\
\text { b. Mengajukan ide-ide baru } \\
\text { c. solusi kreatif }\end{array}$ \\
\hline & & & 5. Kepemimpinan & $\begin{array}{l}\text { a. mendengarkan saran } \\
\text { b. mendengarkan keluhan } \\
\text { c. memberikan motivasi }\end{array}$ \\
\hline & & & 6. Tingkat gaji & $\begin{array}{l}\text { Gaji meningkatkan } \\
\text { semangat kerja }\end{array}$ \\
\hline & & & $\begin{array}{l}\text { 7. Kompensasi tidak } \\
\text { langsung }\end{array}$ & $\begin{array}{l}\text { a. memberikan } \\
\text { penghargaan } \\
\text { b. Employee gathering } \\
\text { c. Fasilitas tempat istirahat }\end{array}$ \\
\hline & & & 8. Lingkungan kerja & $\begin{array}{l}\text { a. Lingkungan kerja } \\
\text { nyaman dan bersih } \\
\text { b. Rekan kerja dan atasan } \\
\text { c. memiliki peraralatan }\end{array}$ \\
\hline \multirow[t]{3}{*}{4} & \multirow[t]{3}{*}{$\begin{array}{l}\text { Kinerja Kerja } \\
(\mathrm{Y})\end{array}$} & \multirow{3}{*}{$\begin{array}{l}\text { Mangkunegara } \\
(2012) \\
\text { mengemukakan } \\
\text { bahwa kinerja adalah } \\
\text { hasil kerja secara } \\
\text { kualitas dan } \\
\text { kuantitas yang di } \\
\text { capai seorang } \\
\text { karyawan dalam } \\
\text { melaksanakan } \\
\text { tugasnya sesuai } \\
\text { dengan tanggung }\end{array}$} & 1. Kuantitas hasil kerja & $\begin{array}{l}\text { a. Hasil kinerja } \\
\text { b. Menyelesaikan } \\
\text { pekerjaan } \\
\text { c. Melakukan pekerjaan } \\
\text { lebih cepat }\end{array}$ \\
\hline & & & 2. Kualitas hasil kerja & $\begin{array}{l}\text { a. Standar kualitas kerja } \\
\text { b. kualitas kerja } \\
\text { c. Karyawan melakukan } \\
\text { pekerjaan dengan teliti }\end{array}$ \\
\hline & & & 3. Ketepatan waktu & $\begin{array}{l}\text { a. hasil kerja yang sesuai } \\
\text { b. Menyelesaikan tugas } \\
\text { sesuai dengan waktu }\end{array}$ \\
\hline
\end{tabular}




\begin{tabular}{|l|l|l|l|}
\hline & $\begin{array}{l}\text { jawab yang } \\
\text { diberikan kepadanya. }\end{array}$ & 4. Efektivitas & $\begin{array}{l}\text { a. Waktu pengerjaan tugas } \\
\text { b. konsentrasi pekerjaan } \\
\text { c. mencapai hasil kerja }\end{array}$ \\
\cline { 3 - 4 } & & 5. Kemandirian & $\begin{array}{l}\text { a. sesuai dengan SOP } \\
\text { b. menyelesaikan pekerjaan } \\
\text { c. pekerjaan secara optimal }\end{array}$ \\
\hline
\end{tabular}

Sumber : Data Diolah 2019

\section{Hasil Penelitian dan Pembahasan}

\section{Uji Analisis Jalur (Path Analysis)}

Uji path analysis digunakan dalam pengujian kontribusi yang ditunjukkan oleh koefisien jalur pada setiap diagram jalur dari hubungan kausal antar variabel X1, X2, terhadap Y serta dampaknya pada Z. Menurut Sani dan Maharani (2013). Untuk mengetahui apakah ada atau tidaknya pengaruh langsung antar variable independent terhadap variable intervening dan variabel intervening terhadap variabel dependen, maupun pengaruh tidak langsung variabel independent terhadap dependent melalui intervening, maka dilakukan uji analisis jalur (Path Analisis) menggunakan SPSS 16 yaitu dengan strategi kausal step dan product of coefficient. Pada strategi kausal step, kristeria hipotesis (Ha) diterima apabila Sig $<0.05$ untuk pengaruh langsung baik secara simultan (nilai F-hitung) maupun parsial, ditambah dengan melihat nilai $t$ untuk melihat nilai pengaruh secara parsial yaitu t-hitung $>$ t-tabel. Untuk melihat signifikansi pengaruh tidak langsung, digunakan strategi product of coefficient dengan melihat nilai z $>1.96$, meskipun apabila dari variable indenpendent ke variabel intervening signifikan dan variable intervening ke variable dependen juga signifikan, tetap dapat diasumsikan bahwa terhadap pengaruh tidak langsung variable indenpendent ke variabel dependent.

\section{Analisis Jalur Model Pertama}

Pada uji analisis jalur model pertama, variable kinerja karyawan dalam persamaan ini dikeluarkan dari model tersusun untuk mendapatkan nilai beta baru dari variable pengembangan karir (X1) dan disiplin kerja (X2) yang signifikan terhadap kepuasan kerja (Z). Setelah variable kinerja karyawan (Y) karyawan dalam persamaan pertama dikeluarkan mendapatkan hasil sebagai berikut : 


\section{Hasil Uji Regresi X1 dan X2 Terhadap Z (Model Pertama)}

\section{Coefficients $^{\mathrm{a}}$}

\begin{tabular}{|c|c|c|c|c|c|c|}
\hline \multirow{2}{*}{\multicolumn{2}{|c|}{ Model }} & \multicolumn{2}{|c|}{ Unstandardized Coefficients } & \multirow{2}{*}{$\begin{array}{c}\text { Standardized } \\
\text { Coefficients } \\
\text { Beta } \\
\end{array}$} & \multirow[b]{2}{*}{$\mathrm{T}$} & \multirow[b]{2}{*}{ Sig. } \\
\hline & & $\mathrm{B}$ & Std. Error & & & \\
\hline \multirow[t]{3}{*}{1} & (Constant) & .463 & .358 & & 1.294 & .198 \\
\hline & PK & .046 & .105 & .032 & .438 & .662 \\
\hline & DK & .827 & .092 & .666 & 8.991 & .000 \\
\hline
\end{tabular}

a. Dependent Variable: Kepuasan Kerja

\section{Model Summary}

\begin{tabular}{|l|l|l|l|l|}
\hline & & & Adjusted R & $\begin{array}{l}\text { Std. Error of the } \\
\text { Estimate }\end{array}$ \\
\hline 1 & .363 & .720 & .094 & .379708 \\
\hline
\end{tabular}

\section{Sumber: Output SPSS 16}

Berdasarkan table diatas, variabel pengembangan karir (X1) berpengaruh signifikan terhadap kepuasan kerja (Z). Hal ini dapat dibuktikan bahwa nilai signifikan variabel pengembangan karir (0.662) lebih besar dari taraf tidak signifikan yaitu 0.05. dan variabel disiplin kerja (0.00) berpengaruh signifikan terhadap kepuasan kerja (Z). Hasil uji statistik menunjukan bahwa ada pengaruh kompetensi secara positif variabel pengembangan karir (X1) terhadap kepuasan kerja $(Z)$ dan ada tidak ada pengaruh kompetensi secara positif variabel disiplin (X2) terhadap kepuasan kerja (Z). Sedangkan nilai e1 bisa dicari dengan menggunakan rumus e1 $=\sqrt{ }(1-0.720=0.530$. Diagram dari jalur model struktur 1 sebagai berikut. 


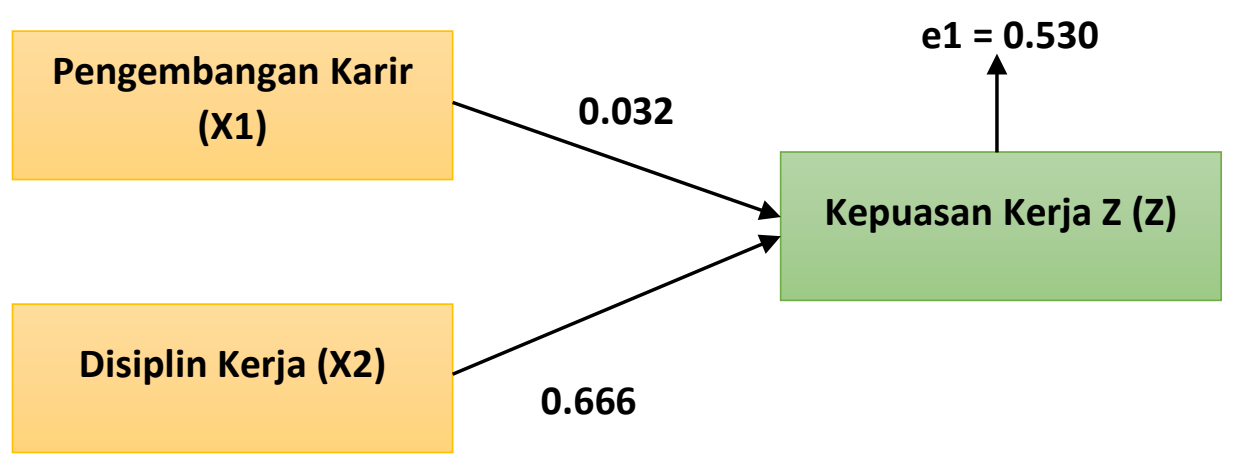

\section{Gambar Hasil Diagram Jalur X1 dan X2 Terhadap Z (Model Pertama)}

\section{Analisis Jalur Model Kedua}

Pada uji analisa jalur model kedua, persamaan yang tersusun adalah pengembangan karir (X1), disiplin kerja (X2) dan kepuasan kerja (Z) terhadap kinerja karyawan (Y). Hasil dari persamaan model kedua ini.

\section{Hasil Uji Regresi X1, X2 Terhadap Y Melalui Z (Model Kedua)}

\begin{tabular}{|c|c|c|c|c|c|c|}
\hline \multicolumn{7}{|c|}{ Coefficients $^{a}$} \\
\hline \multirow{2}{*}{\multicolumn{2}{|c|}{ Model }} & \multicolumn{2}{|c|}{ Unstandardized Coefficients } & \multirow{2}{*}{$\begin{array}{c}\text { Standardized } \\
\text { Coefficients } \\
\text { Beta }\end{array}$} & \multirow[b]{2}{*}{$\mathrm{T}$} & \multirow[b]{2}{*}{ Sig. } \\
\hline & & $\mathrm{B}$ & Std. Error & & & \\
\hline \multirow[t]{4}{*}{1} & (Constant) & .046 & .249 & & .185 & .853 \\
\hline & PK & .186 & .073 & .146 & 2.552 & .012 \\
\hline & DK & .388 & .079 & .349 & 4.897 & .000 \\
\hline & Kepuasan & .408 & .057 & .456 & 7.146 & .000 \\
\hline
\end{tabular}

a. Dependent Variable: KIKAR 
Model Sumarry

\begin{tabular}{|l|r|r|r|r|}
\hline Model & \multicolumn{1}{|c|}{$\mathrm{R}$} & R Square & $\begin{array}{c}\text { Adjusted } \\
\mathrm{R}\end{array}$ & Std. Error of the Estimate \\
\hline 1 & .626 & .901 & .351 & 453.549 \\
\hline
\end{tabular}

Berdasarkan table diatas, variabel pengembangan karir (X1), disiplin kerja (X2) dan kepuasan kerja $(\mathrm{Z})$ berpengaruh signifikan terhadap kinerja karyawan (Y). Hal ini dapat dibuktikan bahwa nilai signifikan variabel pengembangan kerja (X1) (0.012) lebih kecil dari taraf signifikan yaitu 0.05, disiplin kerja (X2) (0.000) dan kepuasan kerja (Z) (0.000) lebih kecil dari taraf signifikan yaitu 0.05 . hasil uji menunjukan bahwa pengembangan karir (X1) pengaruh kompetensi secara positif terhadap kinerja karyawan (Y), disiplin kerja (X2) dan kepuasan kerja (Z) menunjukan bahwa ada pengaruh kompetensi secara positif. Sedangkan nilai e2 bisa dicari dengan menggunakan rumus e $2=\sqrt{ }(1-0.901=0.315$. Diagram dari jalur model struktur 2 sebagai berikut.

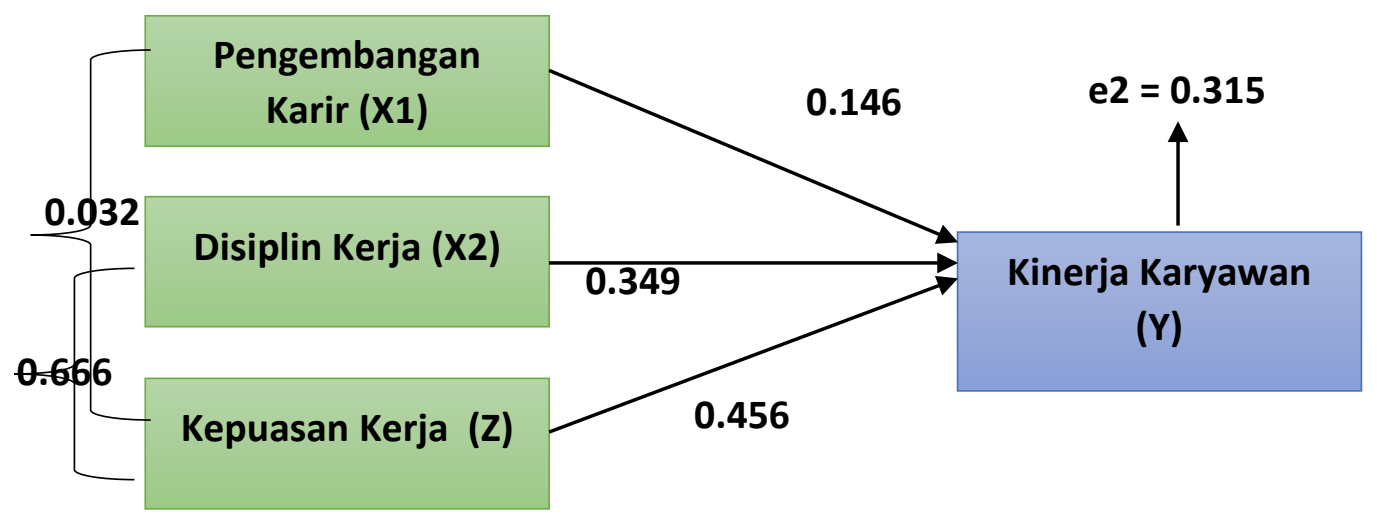

\section{Hasil Diagram Jalur X1, X2 dan Z Terhadap Y (Model Kedua)}




\section{Analisis Jalur Secara Umum}

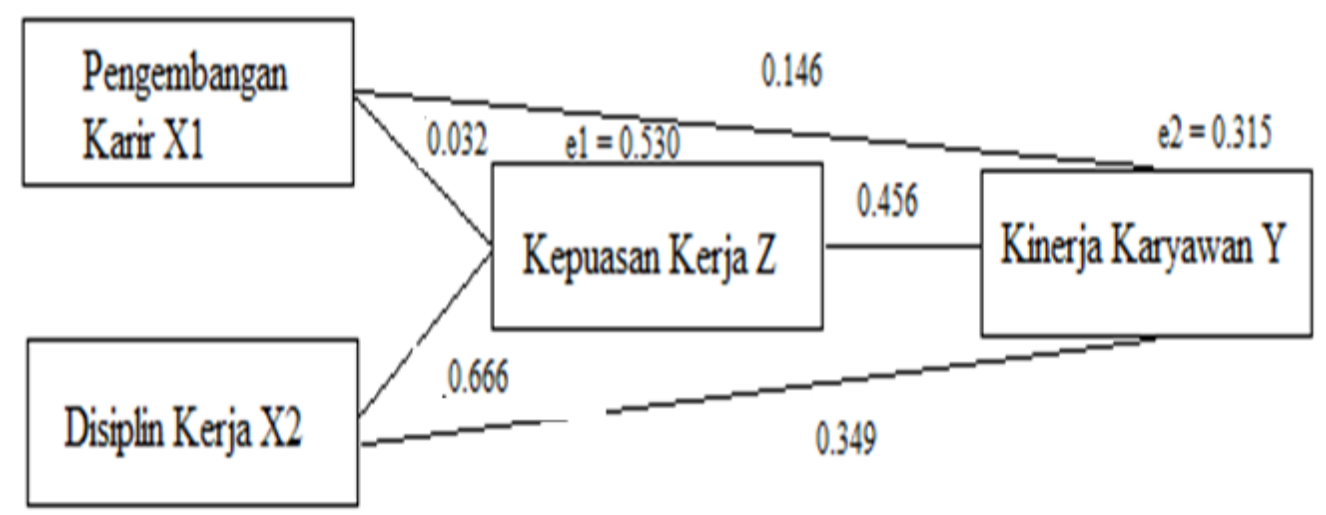

\section{Kerangka Teoritis Regresi X1,X2, Z dan Y (Secara Umum)}

Uji analisis jalur secara umum pada penelitian digunakan untuk menguji apakah ada pengaruh langsung yang diberikan variabel bebas terhadap variable terikat dan pengaruh tidak langsung yang diberikan variable bebas melalui intervening terhadap variable terikat. Persamaan tersusun digunakan untuk mengetahui hubungan antar tiap variable eksogen dengan endogen. Berdasarkan hasil perhitungan analisis jalur struktur model pertama, kedua dan ketiga, maka memberikan informasi secara objektif sebagai berikut:

\section{Hasil Perhitungan Analisis Jalur Struktur}

\begin{tabular}{|l|l|l|l|}
\hline \multirow{2}{*}{\multicolumn{1}{c|}{ Variabel }} & \multicolumn{3}{c|}{ Pengaruh } \\
\cline { 2 - 4 } & \multicolumn{1}{|c|}{ Langsung } & \multicolumn{1}{c|}{ Tidak Langsung } & \multicolumn{2}{c|}{ Total } \\
\hline X1 Terhadap Y & 0.146 & - & 0.146 \\
\hline X1 Terhadap Y Melalui Z & $0.032 \times 0.456$ & 0.015 & 0.047 \\
\hline X2 Terhadap Y & 0,349 & - & 0,349 \\
\hline X2 Terhadap Y Melalui Z & $0.666 \times 0.456$ & 0.303 & 0.969 \\
\hline
\end{tabular}

Sumber: Data diolah, 2019 


\section{Uji Hipotesis dan Pembahasan}

\section{Pengujian hipotesis H1 Pengembangan Karir (X1) berpengaruh langsung terhadap Kinerja Karyawan (Y)}

Pengembangan Karir secara langsung mempengaruhi kinerja karyawan sebesar 0.146 atau 146\%. sisanya sebesar $85,4 \%$ dipengaruhi oleh factor lain diluar penelitian ini. Secara total besarnya pengaruh langsung pengembangan karir terhadap Kinerja Karyawan adalah $0,146 \%$ dan sisanya sebesar $85.4 \%$ di pengaruhi faktor lain diluar penelitian ini. hasil ini menunjukan bahwa secara langsung pengembangan karir mempunyai pengaruh signifikan terhadap kinerja karyawan. Hasil ini ,mendukung penelitian sebelumnya yang dilakukan Yunus (2013), dimana pengembangan karir memiliki pengaruh langsung terhadap kinerja karyawan. Pengembangan karir menjadi perhatian penting bagi setiap karyawan dalam meningkatkan karirnya diperusahaan. Perlu ada peraturan bagi setiap karyawan kontrak mengenai pengembangan karirnya sehingga kinerja mereka akan meningkat. Meningkatnya kinerja karyawan akan meningkatakan kinerja perusahaan.

\section{Pengujian Hipotesis H2 Pengembangan Karir (X1) berpengaruh tidak langsung terhadap Kinerja Karyawan (Y) melalui Kepuasan Kerja (Z)}

Pengembangan Karir secara tidak langsung mempengaruhi Kinerja Karyawan sebesar 0.032 atau $32.00 \%$, secara tidak langsung melalui Kepuasan Kerja sebesar 0.456 atau $45.60 \%$ dan sisanya sebesar $54.40 \%$ dipengaruhi oleh faktor lain diluar penelitian ini. Berdasarkan hasil perhitungan diatas diketahui bahwa nilai pengaruh tidak langsung sebesar 0.032 dan tidak langsung sebesar 0.456 yang berarti bahwa nilai pengaruh tidak langsung lebih besar dari nilai pengaruh langsung, hasil ini menunjukan bahwa secara tidak langsung pengembangan karir melalui kepuasan kerja mempunyai pengaruh tidak signifikan terhadap kinerja karyawan. Hasil ini mendukung penelitian sebelumnya pendapat Dewi, Bagia, Susila (2016) yang menyatakan bahwa adanya pengaruh positif dari pengembangan karir terhadap kinerja karyawan. Pengembangan karir akan menjadi lebih baik bilamana kepuasan kerja karyawan telah terpenuhi yang pada akhirnya akan berdampak pada kinerja karyawan. 


\section{Penguji Hipotesis H3 Disiplin Kerja (X2) berpengaruh langsung terhadap Kinerja Karyawan (Y)}

Disiplin Kerja secara langsung mempengaruhi kinerja karyawan sebesar 0.349 atau 34.90\%. sisanya sebesar $65,1 \%$ dipengaruhi oleh factor lain diluar penelitian ini. Secara total besarnya pengaruh langsung disiplin kerja terhadap Kinerja Karyawan adalah 0,349\% dan sisanya sebesar $65,1 \%$ di pengaruhi faktor lain diluar penelitian ini. Hasil ini menunjukan bahwa secara langsung disiplin kerja terhadap kinerja karyawan mempunyai pengaruh tidak signifikan terhadap kinerja karyawan. Hasil ini mendukung penelitian sebelumnya menurut Riyanto (2016) bahwa disiplin kerja berpengaruh positif dan signifikan terhadap kepuasan kerja. Disiplin kerja perusahaan harus membuat peraturan terhadap disiplin kerja dan harus dipatuhi seluruh karaywan. Dengan dibuatnya aturan da $\mathrm{n}$ diharapkan karaywan akan memiliki disiplin dan kinerja akan semakin meningkat. Sebaliknya bilamana tidak ada aturan maka karyawan akan bertindak tidak sesuai dengan aturan yang berlaku.

\section{Penguji Hipotesis H4 Disiplin Kerja (X2) berpengaruh tidak langsung Terhadap Kinerja} Karyawan (Y) melalui Kepuasan Kerja (Z)

Disiplin Kerja secara langsung mempengaruh Kinerja Karyawan sebesar 0.666 atau 66.60\%, secara tidak langsung melalui Kepuasan Kerja sebesar 0.456 atau $45.60 \%$ dan sisanya sebesar $54.40 \%$ dipengaruhi oleh faktor lain diluar penelitian ini. Berdasarkan hasil perhitungan di atas diketahui bahwa nilai pengaruh langsung sebesar 0.666 dan tidak langsung sebesar 0.456 yang berarti bahwa nilai pengaruh tidak langsung lebih besar dari nilai pengaruh langsung, hasil ini menunjukkan bahwa secara tidak langsung disiplin kerja melalui kepuasan kerja mempunyai pengaruh signifikan terhadap kinerja karyawan. Dengan dibuatnya aturan disiplin kerja dan dilaksanakan oleh karyawan maka karayawan akan menimbulkan kepuasan kerja. Dengan adanya kepuasan kerja maka diharapkan kinerja karyawan akan semakin meningkat. Hasil penelitian ini sejalan dengan penelitian sebelumnya yang dilakukan oleh Bagia (2016) yang menyatakan bahwa ada pengaruh positif dan signifikan antara disiplin kerja terhadap kinerja karyawan. Menurut Susiarto dan Ahmadi (2006). Disiplin kerja karyawan bagian dari factor kinerja. Prasetyo (2008) menyatakan bahwa salah satu factor penentu dari efektifitas kinerja adalah disiplin kerja. Disiplin yang baik mencerminkan besarnya tanggung jawab seseorang 
terhadap tugas-tugasnya yang diberikan kepadanya. Seseorang dikatakan mempunyai disiplin kerja yang tinggi jika yang bersangkutan konsekuen, konsisten, taat asas, bertanggung jawab atas tugas yang diamankan kepadanya. Dengan demikian jelaslah bahwa tujuan yang telah ditetapkan tidak akan terlaksana dengan baik apabila para karyawannya tidak memiliki disiplin kerja yang baik pula. Untuk itu sangat perlu meningkatkan disiplinn kerja pada karyawan agar kinerja karyawan meningkat dan tujuan yang telah ditetapkan oleh perusahaan dapat tercapai dengan baik.

\section{E. Kesimpulan Dan Saran}

Penelitian ini dilakukan untuk menganalisi pengaruh pengembangan karir, disiplin kerja terhadap kinerja karyawan melalui kepuasan kerja sebagai variabel intervening. Berdasarkan hasil analisa dan pengujian hipotesis yang sudah dilakukan pada bab sebelumnya, maka dapat ditarik kesimpulan dari hasil penelitian yang dilakukan sebagai berikut :

Pengembangan karir memiliki pengaruh langsung terhadap kinerja karyawan pada PT XYZ. Yang berarti bahwa apabila pengembangan karir ditingkatkan maka kinerja karyawan akan meningkat. Sebaliknya, apabila pengembangan karir rendah maka kinerja karyawan akan menurun.

Pengembangan karir memiliki pengaruh tidak langsung terhadap kinerja kerja melalui kepuasan kerja pada PT XYZ. Yang berarti bahwa apabila pengembangan karir di tingkatkan maka kepuasan kerja akan meningkat. Sebaliknya, apabila pengembangan karir rendah maka kepuasan kerja akan menurun.

Disiplin kerja memiliki pengaruh langsung terhadap kinerja karyawan pada PT XYZ. Yang berarti bahwa apabila kedisiplinan kerja di tingkatkan maka kinerja karyawan akan meningkat. Sebaliknya, apabila kedisiplinan kerja rendah maka kinerja karyawan akan menurun.

Disiplin kerja memiliki pengaruh tidak langsung terhadap kinerja karyawan melalui kepuasan kerja pada PT XYZ. Yang berarti bahwa apabila displin kerja di tingkatkan maka kepuasan kerja akan meningkat. Sebaliknya, apabila disiplin kerja rendah maka kepuasan kerja akan menurun. 


\subsection{Saran}

Saran bagi PT XYZ yang menjadi objek penelitian ini diharapkan kepada pihak managemen agar memperhatikan disiplin kerja pasalnya, tanpa memperhatikan disiplin kerja sebagaian karyawan menganggap hal yang wajar jika datang terlambat, tidak masuk kerja tanpa keterangan. Saran peneliti adalah perusahaan sebaiknya memberikan sanksi lebih tegas kepada karyawan.

Saran bagi penelitian selanjutnya, dalam penelitian ini masil banyak variabel-variabel yang harus di perhatikan dalam penelitian selanjutnya, karena dalam penelitian ini masih ada beberapa variabel yang tidak diteliti. Seperti motivasi kerja, lingkungan kerja dan kepemimpinan terhadap perusahaan

\section{DAFTAR PUSTAKA}

\section{Buku:}

Hasabuan Melayu (2001), Manajemen Sumber Daya Manusia edisi Revisi, Penerbit Bumi kasara Jakarta.

Hasibuan Melayu (2003), Organisasi dan motivasi : Dasar peningkatan Produktivitas Penerbit Bumi kasara Jakarta.

Hasibuan Melayu (2006), Manajemen Sumber Daya Manusia edisi Revisi, Penerbit Bumi kasara Jakarta.

Mangkunegara (2011), Manajemen Sumber Daya Manusia Perusahaan, Bandung : Rosda.

Mangkunegara (2012), Evaluasi Kinerja SDM cetakan ke enam. Bandung : Aditama

Panji (2009), Manajemen bisnis, Semarang : PT.Rineka Cipta

Robbins S.P (1996), Perilaku Organisasi edisi kesepuluh, Penerbit indeks Gramedia, Yogyakarta.

Rivai, Veithzal (2011), Manajemen Sumber Daya Manusia untuk Perusahaan: dari Teori ke Praktik, Jakarta : Raja Grafindo Persada.

Rachmawati (2008), Manajemen Sumber Daya Manusia, Yogyakarta : ANDI.

Rianto, Dedi, (2015). Structural Equation Modeling Dalam Penelitian Manajemen Sistem 
Informasi.

Sunyoto, D (2012). Manajemen Sumber Daya Manusia. Yogyakarta : CAPS.

Wibowo, (2009) Manajemen kinerja-edisi ke 2. Jakarta: Rajawali Pers.

\section{Jurnal:}

Lumentut Mauritz D.S (2015). "Pengaruh Motivasi, Disiplin, dan Lingkungan Kerja terhadap Kepuasan Karyawan pada PT.Bank Sulut Cabang Airmadidi,"Jurnal EMBA Vol. 3 No. 1. Universitas Sam Ratulangi Manado.

Margareth, Helga. (2012). Pengaruh Motivasi Kerja Terhadap Kinerja Karyawan (Kasus Pada Divisi Network Management Pt Indosat, Tbk.) : Universitas Bakrie Jakarta.

Putra S.D (2014). "Pengaruh budaya organisasi, kompensasi dan pengembangan Karir terhadap kepuasan kerja perawat serta dampaknya terhadap kinerja Perawat badan layanan umum daerah rumah sakit jiwa aceh," Fakultas Ekonomi Universitas Syiah Kuala.

Siagian .S.S (2015). "Pengaruh pelatihan, kepuasan kompensasi, motivasi dan Disiplin kerja terhadap kinerja karyawan,” Sekolah tinggi Ilmu Ekonomi Indonesia (STIESIA).

\section{Skripsi:}

Dewi, B.S. (2017). Pengaruh tingkat pendidikan dan pengembangan karir terhadap Kinerja karyawan. Bandung: Fakultas Komunikasi dan Bisnis, Universitas Telkom.

Rahardjo. (2017). Pengaruh pendidikan dan pelatihan, Pengembangan karir dan Kepuasan kerja terhadap kinerja karyawan. Surakarta: Universitas Sebelas Maret.

Riyanto, B.P (2016). Pengaruh motivasi kerja dan disiplin kerja terhadap kepuasan Kerja karyawan bank tabungan negara Yogyakarta. Yogyakarta : Universitas Negri Yogyakarta.

\section{Internet:}

PT.Multistrada Arah Sarana Tbk. 2018. http://www.multistrada.co.id/investor-relations/annualreports/. Diakses 11 April 2018.

Raharjo, Sahid. 2017. Cara Uji Analisis Jalur [Path Analysis] dengan SPSS Lengkap. http://www.spssindonesia.com/2017/03/cara-uji-analisis-jalur-path-analysis.html. Diakses 03 April 2018. 